\title{
LOW DOSE OF COPPER IS MORE EFFECTIVE ON INTESTINAL MORPHOLOGY IN WEANED PIGS
}

(Baixa dose de cobre é mais eficaz na morfologia intestinal de leitões desmamados)

\begin{abstract}
Willian Hideharu de Eiroz Okiyama ${ }^{1}$, Maitê Vidal Mendonça², Ana Paula Pinoti Pavaneli ${ }^{3}$ Simone Maria

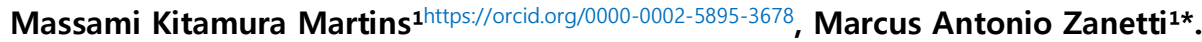

\section{${ }^{1}$ Faculty of Animal Science and Food Engineering, University of São Paulo (FZEA-USP), Pirassununga - SP, Brazil; ${ }^{2}$ Department of Animal Nutrition and Production, School of Veterinary Medicine and Animal Science, Pirassununga, São Paulo, Brazil; ${ }^{3}$ Department of Animal Reproduction, School of Veterinary Medicine and Animal Science, Pirassununga, São Paulo, Brazil.}

*Corresponding author: mzanetti@usp.br

Editora de Seção: Juliana Sperotto Brum Editora: Julia Arantes Galvão

ABSTRACT - The present experiment was carried out to determine the relation between pharmacological levels of copper (Cu) 125 and $200 \mathrm{mg} / \mathrm{kg}$ ) and source (cooper sulfate $\left(\mathrm{CuSO}_{4}\right)$ and tribasic copper chloride (TBCC)) on growth performance, diarrhea incidence and intestinal morphology of piglets after weaning. At 21 days of age, 96 weaned piglets were sorted by body weight (BW, $6.14 \pm 0.269 \mathrm{~kg})$ and randomly assigned to 4 treatments according to a block design of a $2 \times 2$ factorial arrangement: level (125 and $200 \mathrm{mg} / \mathrm{kg}$ ) and source $\left(\mathrm{CuSO}_{4}\right.$ or TBCC). Growth performance was evaluated by measuring BW, average daily feed intake (ADFI), average daily gain (ADG) and feed conversion ratio (FCR) from 21 to 63 days of age. Fecal score was evaluated daily and at 63 days of age tissue samples were collected from the duodenum, jejunum and ileum for intestinal morphology analysis. At this moment, it was evaluated villus height $(\mathrm{VH})$ crypt depth (CD) and villus height to crypt depth ratio ( $\mathrm{VH}: \mathrm{CD}$ ratio). There was no difference between level and source $(P>0.05)$ for any growth performance. Piglets fed $200 \mathrm{mg} / \mathrm{kg}$ TBCC had the lowest diarrhea frequency $(\mathrm{P}<0.05)$ in overall nursery period than the other treatments during the whole experimental period. Supplementation with $125 \mathrm{mg} / \mathrm{kg}$ increased $\mathrm{VH}(\mathrm{P}<0.05)$ and $\mathrm{VH}: \mathrm{CD}$ ratio $(\mathrm{P}<0.05)$ in the duodenum when compared to $200 \mathrm{mg} / \mathrm{kg}$, regardless of the source. Based on our results, we can conclude that $125 \mathrm{mg} / \mathrm{kg}$ of $\mathrm{Cu}$ improve the $\mathrm{VH}$ and $\mathrm{VH}: \mathrm{CD}$ ratio in the duodenum and may show growth performance results similar to $200 \mathrm{mg} / \mathrm{kg}$ of $\mathrm{Cu}$.

Key words: Copper sulfate; pharmacological level; tribasic copper chloride; weaning.

RESUMO - O presente experimento foi realizado para determinar a relação entre os níveis farmacológicos de cobre (Cu) (125 e 200 mg/kg) e a fonte (sulfato de cobre 
$\left(\mathrm{CuSO}_{4}\right)$ e cloreto de cobre tribásico $(\mathrm{TBCC})$ ) sobre o desempenho, a incidência de diarreia e morfometria intestinal dos leitões após o desmame. Aos 21 dias de idade, 96 leitões desmamados foram separados pelo peso corporal ( $P C, 6,14 \pm 0,269 \mathrm{~kg}$ ) e distribuídos aleatoriamente em 4 tratamentos, segundo delineamento em blocos e arranjo fatorial 2 x 2: nível (125 e $200 \mathrm{mg} / \mathrm{kg}$ ) e fonte $\left(\mathrm{CuSO}_{4}\right.$ ou TBCC). O desempenho foi avaliado através da mensuração do peso corporal, consumo de ração médio diário (CRMD), ganho de peso médio diário (GPMD) e conversão alimentar (CA) dos 21 aos 63 dias de idade. A consistência fecal foi avaliada diariamente e, aos 63 dias de idade, foram coletadas amostras de tecido do duodeno, jejuno e íleo para análise da morfometria intestinal. Neste momento, foram avaliadas a altura da vilosidade (AV), profundidade da cripta (PC) e relação altura da vilosidade:profundidade da cripta $(A V: P C)$. Não houve diferença entre nível e fonte $(P>0,05)$ para o desempenho. Os leitões alimentados com $200 \mathrm{mg} / \mathrm{kg}$ de TBCC apresentaram menor incidência de diarreia $(P<0,05)$ do que os outros tratamentos durante todo o período experimental. A suplementação com $125 \mathrm{mg} / \mathrm{kg}$ aumentou o $\mathrm{AV}(\mathrm{P}<0,05)$ e a relação $\mathrm{AV}: \mathrm{PC}(\mathrm{P}<0,05)$ no duodeno, quando comparado a $200 \mathrm{mg} / \mathrm{kg}$, independentemente da fonte. Com base em nossos resultados, podemos concluir que os leitões suplementados com $125 \mathrm{mg} / \mathrm{kg}$ de $\mathrm{Cu}$ tiveram melhor $\mathrm{AV}$ e relação $\mathrm{AV}: \mathrm{PC}$ no duodeno e demonstram resultados de desempenho semelhantes ao $200 \mathrm{mg} / \mathrm{kg}$ de $\mathrm{Cu}$.

Palavras-chave - Cloreto de cobre tribásico; desmame; nível farmacológico; sulfato de cobre.

\section{INTRODUCTION}

Weaning is a critical event that directly related to piglet's productivity and subsequently, profitability for the producer. As a result of this stressful event, changes may occur in the post-weaning period about gastrointestinal physiology, microbiology, and immunology. Therefore, the post-weaning period is often characterized by a high incidence of diarrhea and depression in piglet's growth performance (Heo et al., 2013).

The use of copper $(\mathrm{Cu})$ in diet can help animals face new challenges, especially in the antibiotic ban, as growth promoters. The supplementation of $\mathrm{Cu}$ at pharmacological levels (100 to $250 \mathrm{mg} / \mathrm{kg}$ ) post-weaning has been associated with improving growth performance, feed intake and efficiency of feed utilization in weanling pigs (Cromwell et al., 1998; Hill et al., 2000; Armstrong et al., 2004; Shelton et al., 2011; Ma et al., 2015; Bikker et al., 2016; Carpenter et al., 2019, Lin et al., 2020). However, Cu as copper sulfate $\left(\mathrm{CuSO}_{4}\right)$ is poorly absorbed, around $15-30 \%$ of the ingested in young animals, and $5-10 \%$ in adult animals (Gattás; Barbosa, 2004) and thereby it is necessary to know a different 
kind of sources in order to reduce the environmental impact generated by this management.

The most used source of $\mathrm{Cu}$ is copper sulfate $\left(\mathrm{CuSO}_{4}\right)$. Nevertheless, it has been reported that tribasic copper chloride (TBCC) to be equally effective as $\mathrm{CuSO}_{4}$ for improving the performance of weanling pigs (Cromwell et al., 1998; Fry et al., 2012). Tribasic copper chloride is a less reactive form of $\mathrm{Cu}$ and is a potential alternative to $\mathrm{CuSO}_{4}$ (Kim and Kil, 2015). Due to its lower hygroscopicity and solubility in water and the crystalline structure of the TBCC, it dissolves slowly in the digestive tract, leading to greater efficacy (Olukosi et al., 2018). Furthermore, the TBCC-complex possesses a stronger bonding that can be responsible for reduced reactiveness with other components of the diet and improve bioavailability (Cemin et al., 2017). Also, tribasic copper chloride is a possible solution for reducing $\mathrm{Cu}$ excretion in the environment.

Thus, this study aimed to evaluate the effects of association between the pharmacological levels (125 or $200 \mathrm{mg} / \mathrm{kg}$ ) and source $\left(\mathrm{CuSO}_{4}\right.$ or $\mathrm{TBCC}$ ) of $\mathrm{Cu}$ on performance, diarrhea incidence, and intestinal morphology piglets after weaning.

\section{MATERIAL AND METHODS}

The procedures and experimental use of animals were approved by the Ethic Committee on Animal Use (CEUA) with the rules issued by the National Council for Control of Animal Experimentation (CONCEA), protocol number 6255070515.

Ninety-six commercial crossbred [(Large White $\times$ Landrace $) \times$ Duroc] weanling piglets of 21 days of age were used for this trial. The animals were distributed into four treatments based on BW, according to a block design of a $2 \times 2$ factorial arrangement: level (125 or $200 \mathrm{mg} / \mathrm{kg}$ ) and source $\left(\mathrm{CuSO}_{4}\right.$ or $\left.\mathrm{TBCC}\right)$. The piglets received one of four treatments: $125 \mathrm{mg} / \mathrm{kg}$ of $\mathrm{CuSO}_{4}, 125 \mathrm{mg} / \mathrm{kg}$ of TBCC, $200 \mathrm{mg} / \mathrm{kg}$ of $\mathrm{CuSO}_{4}$ and 200 $\mathrm{mg} / \mathrm{kg}$ of TBCC.

It was prepared a basal diet based on Rostagno et al. (2017) recommendations with the mineral's inclusion according to the treatments. The animals were housed in two climate-controlled rooms for nursery pigs, with 12 pens of $1.2 \mathrm{~m} 2 / 4$ piglets. Each treatment consisted of 6 replicate pens with 4 animals each ( 2 males and 2 females).

Water and feed were supplied ad libitum and feed was offered according to the period of the rearing cycle, described below: pre-starter I period, from 21 to 28 days of age; pre-starter II period, from 28 to 35 days of age; starter I period, from 35 to 49 days of age, and starter 2 period, from 49 to 63 days of age (Table 1). Zinc oxide (ZnO) was supplemented at $2,500 \mathrm{mg} / \mathrm{kg}$ to all treatments during the pre-starter periods I and II. 
Low dose of copper is more effective on intestinal morphology in weaned pigs

The piglets' performance was evaluated by measuring BW at 21, 28, 35, 49 and 63 days of age. The average daily gain (ADG), average daily feed intake (ADFI) and feed conversion ratio (FCR) were calculated for each interval.

Visual analysis of the feces on the pen's floor was carried out every day, with scores ranging from 1 to 3 for each pen: 1 = solid feces (normal); 2 = feces softer than normal (pasty); and 3 = liquid feces (severe diarrhea) according to Pascoal et al. (2012) with modifications. Subsequently, it was calculated the diarrhea incidence, considering diarrhea the sum of scores 2 and 3.

On day 63, six piglets per treatment, 3 males and 3 females, were euthanized by electronarcosis and subsequent exsanguination to collect samples from the duodenum, jejunum and ileum. Tissue samples, with a length of $3 \mathrm{~cm}$ were collected and gently washed using $\mathrm{NaCl}$ solution $9 \%$, pinned on cork and fixed in a $10 \%$ formalin solution for 24 hours for histological examination. Formalin-fixed samples were embedded in paraffin, sectioned at a $5 \mu \mathrm{m}$ thickness, and stained with hematoxylin and eosin for histological examination.

Characteristics determined during examination were villus height $(\mathrm{VH})$, crypt depth (CD) and villus height:crypt depth ratio (VH:CD). Samples were examined using a Nikon Eclipse $\mathrm{Ni}-\mathrm{U} 8 \mathrm{8}^{\circledR}{ }^{\circledR}$ light microscope (Nikon Instruments Inc., Melville, NY) coupled to a Nikon DigitalSight DS RI ${ }^{\circledR}$ camera (Nikon Instruments Inc., Melville, NY). The parameters were determined using NIS Elements AR $413.01^{\circledR}$ software (Nikon Instruments Inc., Melville, NY). To perform the analysis, it was used at 10x magnification (Pekas, 1986).

Data were analyzed using the MIXED procedure of SAS software (Statistical Analysis System, version 9.3), according to a block design containing treatments as fixed effect and body weight as random effect. Each pen was considered as one experimental unit. Effect of treatment and time were evaluated using PDIFF. Data on the frequency of diarrhea was evaluated by the chi-square method. Differences were considered significant when $P<0.05$ and marginally significant when $P<0.10$ and $P \geq 0.05$. All results were expressed as mean values and standard deviations.

The statistical model used to test the effect of treatments and blocks was

$Y_{-} i j k=\mu+B_{-} j+L_{-} i+S_{-} k+\varepsilon_{-} i j k$, in which $Y_{i j k}$ is the quantitative response variable; $\mu$ is the overall mean; $L$ is the effect of level (" $i "=125$ and $200 \mathrm{mg} / \mathrm{kg}$ ), $\mathrm{S}$ is the effect of source (" $k "=\mathrm{CuSO}_{4}$ and TBCC); B is the effect of block ("j" = BW); and $\varepsilon$ is the random error. 
Table 1. Composition of experimental diets (as-fed basis) provided to the weaned piglets (from 21 to 63 days of age)., 1,3

\begin{tabular}{|c|c|c|c|c|}
\hline Ingredients, g/kg & Pre-starter I & Pre-starter II & Starter I & Starter II \\
\hline Ground corn & 486.00 & 525.00 & 617.90 & 663.30 \\
\hline Soybean meal & 190.00 & 250.00 & 300.00 & 300.00 \\
\hline Milk whey & 186.30 & 124.60 & - & - \\
\hline Whole milk powder & 20.00 & 25.20 & - & - \\
\hline Degummed soybean oil & 22.90 & 8.40 & 11.80 & 7.00 \\
\hline Spray-dried plasm & 42.00 & 15.00 & - & - \\
\hline Sugar & 20.00 & 20.00 & 20.00 & - \\
\hline Limestone & - & 6.10 & 4.10 & 8.70 \\
\hline Fish meal & - & - & 22.00 & - \\
\hline Dicalcium phosphate & 15.70 & 8.60 & 6.90 & 6.20 \\
\hline Salt & - & 4.00 & 5.70 & 4.70 \\
\hline Choline chloride & - & - & - & 0.80 \\
\hline L-Lysine HCL & 4.20 & 3.00 & 2.80 & 2.00 \\
\hline DL-Methionine & 3.60 & 2.50 & 1.90 & 1.20 \\
\hline L-Threonine & 2.90 & 1.50 & 1.20 & 0.60 \\
\hline L-Tryptophan & 0.90 & 0.30 & 0.20 & 0.05 \\
\hline L-Valine & 0.40 & 0.70 & - & - \\
\hline Vitamin and mineral premix ${ }^{4}$ & 5.00 & 5.00 & 5.00 & 5.00 \\
\hline \multicolumn{5}{|c|}{ Calculated composition, $\mathrm{g} / \mathrm{kg}$} \\
\hline $\mathrm{ME}, \mathrm{kcal} / \mathrm{kg}$ & 3450.00 & 3400.00 & 3380.00 & 3350.00 \\
\hline Crude protein & 184.10 & 190.30 & 198.20 & 198.50 \\
\hline Calcium & 5.50 & 6.20 & 6.00 & 6.00 \\
\hline Available phosphorus & 5.70 & 4.90 & 4.40 & 3.70 \\
\hline SID lysine & 12.70 & 11.70 & 11.20 & 10.50 \\
\hline SID met + cys & 6.40 & 6.20 & 6.10 & 6.10 \\
\hline SID threonine & 7.00 & 6.50 & 6.30 & 6.20 \\
\hline SID Tryptophan & 2.10 & 1.80 & 1.80 & 1.80 \\
\hline Sodium & 3.60 & 3.60 & 2.60 & 2.00 \\
\hline
\end{tabular}

SID - standardized ileal digestible.

${ }^{1} \mathrm{CuSO}_{4}$ was added to the basal diets at the expense of ground corn at 0.5 and $0.8 \mathrm{~g} / \mathrm{kg}$ of diet to achieve the dietary concentrations of 125 and $200 \mathrm{mg} / \mathrm{kg} \mathrm{Cu}$, respectively, for each period (as-fed basis).

${ }^{2}$ TBCC was added to the basal diets at the expense of ground corn at 0.23 and $0.37 \mathrm{~g} / \mathrm{kg}$ of diet to achieve the dietary concentrations of 125 and $200 \mathrm{mg} / \mathrm{kg} \mathrm{Cu}$, respectively, for each period (as-fed basis).

${ }^{3}$ The chemical composition was not determined.

${ }^{4}$ Vitamin and mineral premix (per $\mathrm{kg}$ of product): folic acid $3.2 \mathrm{mg}$, pantothenic acid $18 \mathrm{mg}$, biotin $0.2 \mathrm{mg}$, cobalt $0.1 \mathrm{mg}$, choline $562.5 \mathrm{mg}$, iron $125 \mathrm{mg}$, iodine $1.2 \mathrm{mg}$, manganese $48 \mathrm{mg}$, niacin $38 \mathrm{mg}$, selenium 0.5 mg, thiamine $3 \mathrm{mg}$, vitamin A $20250 \mathrm{IU}$, vitamin B12 $46.5 \mathrm{mg}$, vitamin B2 $7.3 \mathrm{mg}$, vitamin B6 $4 \mathrm{mg}$, vitamin C $400 \mathrm{mg}$, vitamin D3 $5265 \mathrm{IU}$, vitamin E $150 \mathrm{IU}$, vitamin K3 $5.26 \mathrm{mg}$, zinc 2,500 mg/kg (Pre-starter 1 and 2), zinc $150 \mathrm{mg} / \mathrm{kg}$ (Starter 1 and 2).

\section{RESULTS}

Growth performance were not affected by level or source of dietary $\mathrm{Cu}(P>0.05$, Table 2). Interaction between level and source was observed in diarrhea frequency, from 21 to 63 days of age. The lowest diarrhea frequency $(P<0.05)$ was observed when the piglets received $200 \mathrm{mg} / \mathrm{kg} \mathrm{Cu}$ as TBCC (Figure 1). The increase of concentration from 125 to $200 \mathrm{mg} / \mathrm{kg} \mathrm{Cu}$ as TBCC led to reduction of 75\% on the diarrhea frequency, and a decrease on diarrhea (75.75\%) it also was verified when compared $\mathrm{CuSO}_{4}$ to $\mathrm{TBCC}$ source. 
On intestinal morphology analysis, the jejunum was the only segment that was not observed differences among treatments $(P>0.05$, Table 3$)$. Piglets that received 125 $\mathrm{mg} / \mathrm{kg} \mathrm{Cu}$ had an enhance of $18.46 \%$ in $\mathrm{VH}$ in duodenum compared with the piglets that received $200 \mathrm{mg} / \mathrm{kg}$ ( $P<0.05$, Table 3 ). An increase of $29.17 \%$ was observed in the $\mathrm{VH}: \mathrm{CD}$ ratio in duodenum of animals $125 \mathrm{mg} / \mathrm{kg} \mathrm{Cu}$ in regarding to group that received 200 $\mathrm{mg} / \mathrm{kg}(\mathrm{P}<0.05$, Table 3$)$, and also was verified marginally increase in $20.88 \%$ in this same relation in the piglets that received the TBCC source compared to $\mathrm{CuSO}_{4}$ source $(P<0.10$, Table 3). In the piglets that received the source $\mathrm{CuSO}_{4}$ was observed marginal enhance in $12.42 \% C D$ in duodenum segment in comparison to TBCC source $(P<0.10$, Table 3$)$.

Table 2. Effects of association between copper levels and source on growth performance of weaned piglets (from 21 to 63 days of age). ${ }^{1}$

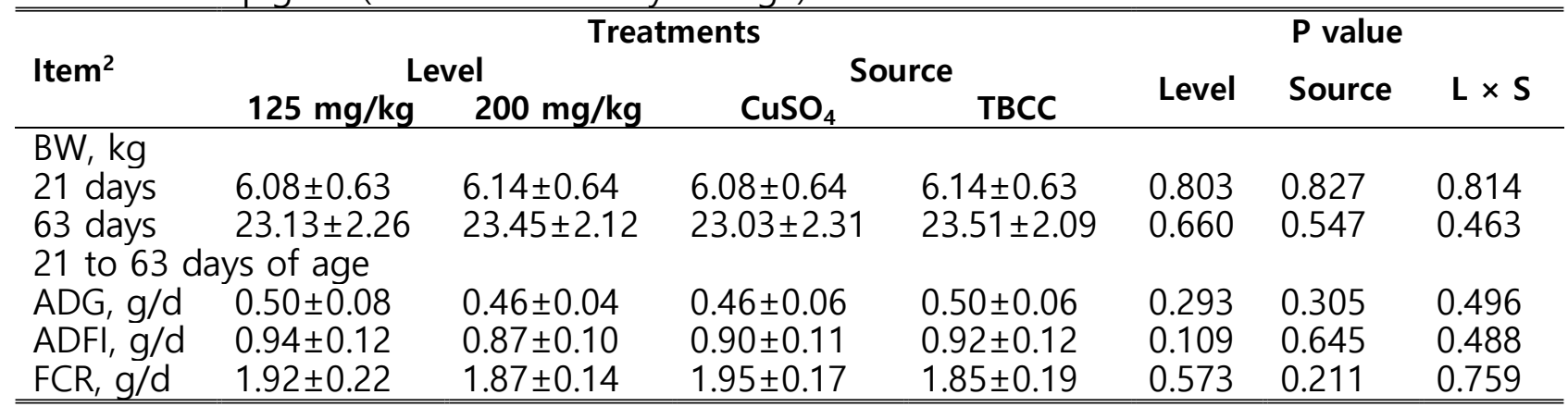

${ }^{1}$ Treatments: Level, 125 or $200 \mathrm{mg} / \mathrm{kg}$; source, $\mathrm{CuSO}_{4}$ or TBCC.

${ }^{2}$ Abbreviations: BW, Body weight; ADG, Average Daily Gain; ADFI, Average Daily Feed Intake; FCR, Feed Conversion Ratio; $\mathrm{CuSO}_{4}$, copper sulfate; TBCC, tribasic copper chloride; $\mathrm{L} \times \mathrm{S}$, interaction level and source.

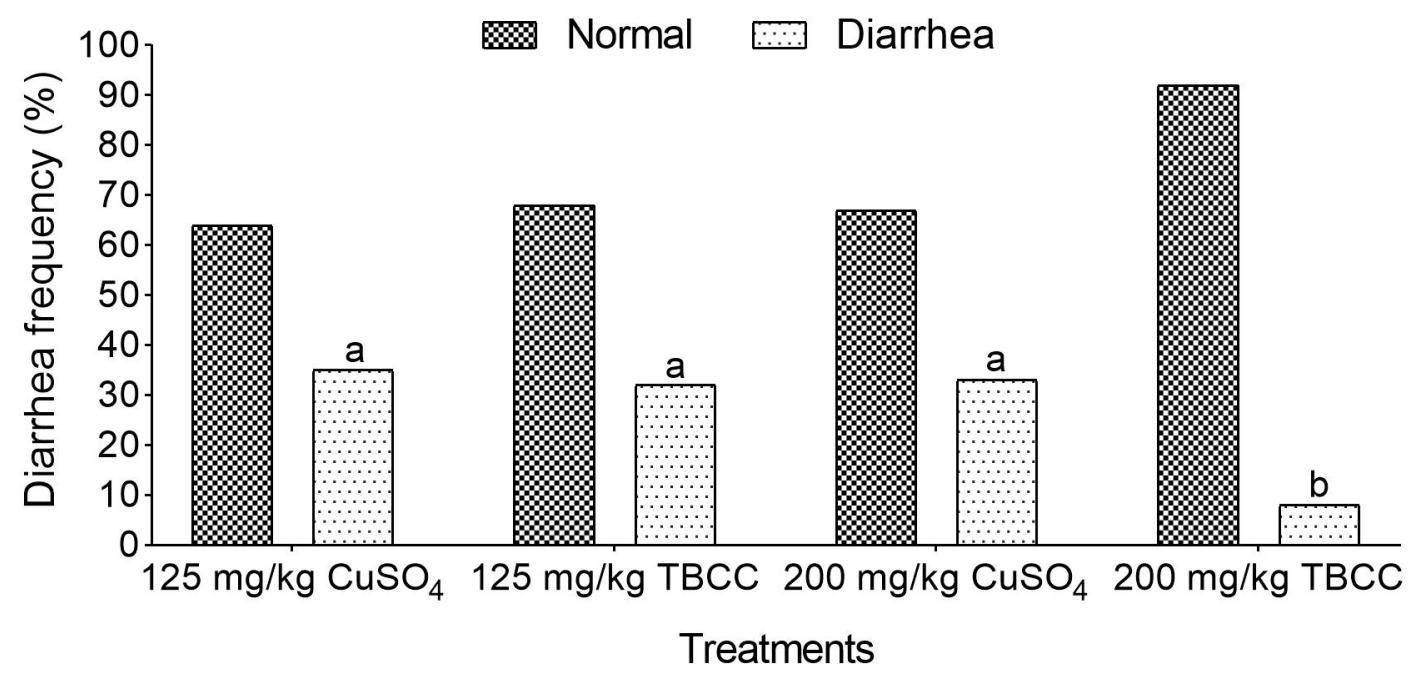

a,b Means with different superscript differ (Chi-square, $\mathrm{P}<0.05)$

Figure 1. Frequency of diarrhea of piglets from 21 to 63 days of age. 
Table 3. Effects of association between copper levels and source on the intestinal morphology of weaned piglets (from 21 to 63 days of age). ${ }^{1}$

\begin{tabular}{|c|c|c|c|c|c|c|c|}
\hline \multirow[b]{2}{*}{ Item $^{2}$} & \multicolumn{4}{|c|}{ Treatments } & \multicolumn{3}{|c|}{$P$ value } \\
\hline & \multicolumn{2}{|c|}{ Level } & \multicolumn{2}{|c|}{ Source } & Level & Source & $L \times S$ \\
\hline \multicolumn{8}{|c|}{ Duodenum $(\mu \mathrm{m})$} \\
\hline VH & $377.78 \pm 62.87^{a}$ & $308.03 \pm 64.08^{b}$ & $343.62 \pm 68.86$ & $338.96 \pm 77.67$ & 0.025 & 0.900 & 0.846 \\
\hline$C D$ & $442.41 \pm 98.69$ & $456.06 \pm 48.78$ & $478.98 \pm 66.30^{A}$ & $419.49 \pm 76.78^{B}$ & 0.656 & 0.064 & 0.653 \\
\hline $\mathrm{VH}: \mathrm{CD}$ & $0.96 \pm 0.27^{a}$ & $0.68 \pm 0.15^{b}$ & $0.72 \pm 0.15^{B}$ & $0.91 \pm 0.31^{A}$ & 0.019 & 0.074 & 0.199 \\
\hline \multicolumn{8}{|c|}{ Jejunum ( $\mu \mathrm{m})$} \\
\hline $\mathrm{VH}$ & $317.76 \pm 68.49$ & $290.74 \pm 67.01$ & $294.15 \pm 53.18$ & $314.35 \pm 80.80$ & 0.275 & 0.540 & 0.440 \\
\hline$C D$ & $368.87 \pm 75.10$ & $374.79 \pm 85.50$ & $381.04 \pm 61.45$ & $362.62 \pm 94.91$ & 0.886 & 0.838 & 0.683 \\
\hline $\mathrm{VH}: \mathrm{CD}$ & $0.90 \pm 0.29$ & $0.82 \pm 0.29$ & $0.80 \pm 0.25$ & $0.92 \pm 0.32$ & 0.510 & 0.361 & 0.228 \\
\hline \multicolumn{8}{|c|}{ lleum $(\mu \mathrm{m})$} \\
\hline VH & $299.22 \pm 62.40$ & $261.30 \pm 45.16$ & $302.98 \pm 58.02^{\mathrm{A}}$ & $253.75 \pm 43.23^{B}$ & 0.207 & 0.099 & 0.108 \\
\hline$C D$ & $325.49 \pm 77.94^{\mathrm{A}}$ & $262.19 \pm 66.00^{B}$ & $292.67 \pm 68.93$ & $295.01 \pm 88.67$ & 0.063 & 0.942 & 0.478 \\
\hline $\mathrm{VH}: \mathrm{CD}$ & $0.99 \pm 0.17$ & $1.06 \pm 0.36$ & $1.07 \pm 0.23$ & $0.99 \pm 0.32$ & 0.573 & 0.515 & 0.997 \\
\hline
\end{tabular}

ab Means without a common superscript letter differ (PDIFF, $\mathrm{P}<0.05)$.

$A B$ Means without a common superscript letter trend differ ( $P D I F F, P<0.10)$.

${ }^{1}$ Treatments: Level, 125 or $200 \mathrm{mg} / \mathrm{kg}$; source, $\mathrm{CuSO}_{4}$ or TBCC.

${ }^{2}$ Abbreviations: $\mathrm{VH}$, Villus Height; $\mathrm{CD}$, Crypt Depth; $\mathrm{VH}: \mathrm{CD}$, relation villus height: crypt depth: $\mathrm{CuSO}_{4}$, copper sulfate; TBCC, tribasic copper chloride; $L \times S$, interaction level and source.

In the piglets that received the source $\mathrm{CuSO}_{4}$ was observed marginal enhance in $12.42 \%$ CD in duodenum segment in comparison to TBCC source $(P<0.10$, Table 3$)$. No effect to level of $\mathrm{Cu}$ was observed in $C D$, as well as no effect of $\mathrm{Cu}$ source was verified to $\mathrm{VH}$ and $\mathrm{VH}: \mathrm{CD}$ ratio in this segment $(\mathrm{P}>0.05)$.

In ileum of animals that received the $\mathrm{CuSO}_{4}$ source, it was verified marginal increase in $16.25 \% \mathrm{VH}$ compared to TBCC source $(\mathrm{P}<0.10$, Table 3$)$. It also was observed in the piglets that received $125 \mathrm{mg} / \mathrm{kg}$ Cu marginally greater CD (19.45\%) to $200 \mathrm{mg} / \mathrm{kg}$ $(\mathrm{P}<0.10$, Table 3$)$. No effect to $\mathrm{Cu}$ source was verified to $\mathrm{CD}$ and $\mathrm{VH}: \mathrm{CD}$ ratio, as well as no effect to level was observed to $\mathrm{VH}$ and $\mathrm{VH}: \mathrm{CD}$ ratio in this segment $(P>0.05)$.

\section{DISCUSSION}

The copper $(\mathrm{Cu})$ is an essential trace element and is involved in several metabolic processes. The supplementation in piglets' diet at higher concentrations $(100-250 \mathrm{mg} / \mathrm{kg}$ ) to improve growth performance, and reduce the diarrhea incidence (Cromwell et al., 1998, Hill et al., 2000, Davis et al., 2002; Shelton et al., 2011; Ma et al., 2015, Carpenter et al., 2019, Lin et al., 2020), and the use this mineral become essential especially in the context of the antibiotic ban, as growth promoters.

In the present study, the supplementation of $\mathrm{Cu}$ (level or source) did not affect growth performance piglets. These results were similar to those reported by Comwell et al. (1998), Veum et al. (2004), Pérez et al. (2011), Shelton et al. (2011), Fry et al. (2012) 
Low dose of copper is more effective on intestinal morphology in weaned pigs

and Bikker et al. (2016). The researches mentioned above verified differences between pig supplemented with high concentration compared to the control group (low level of $\mathrm{Cu}$ ), but the growth performance was similar among the animals that received high concentration $\mathrm{Cu}$, as in our study.

Others previous studies have found opposite responses with improve in BW and ADG (Zhao et al., 2014, $170 \mathrm{mg} / \mathrm{kg}$ copper 2-hydroxy-4-(methylthio) butanoic acid (Cu(HMTBa)2)), and it also enhances in G:F was reported by Carpernter et al. (2019) with $225 \mathrm{mg} / \mathrm{kg} \mathrm{Cu}$, and Lin et al. (2020) with $160-200 \mathrm{mg} / \mathrm{kg}$ TBCC or $80-160 \mathrm{mg} / \mathrm{kg}$ copper proteinate (CuPro). This considerable variation observed in the literature results can be partially attributed to chemical variations inherent to different mineral sources, resulting in differences in efficacy, bioavailability and probably different absorption routes (Aldridge et al., 2007). Other factors may also contribute to inconsistent results, such as the duration and levels of supplementation (Hill et al., 2000), ingredients in the diet (Coble et al., 2018) and health condition of the animals (Zhao et al., 2007; Debski, 2016).

In this study, the animals that received $200 \mathrm{mg} / \mathrm{kg} \mathrm{Cu}$ from TBCC showed the lowest diarrhea frequency in the overall period. A reduction of $75.00 \%$ in diarrhea was observed due to an increase in concentration Cu (from 125 to $200 \mathrm{mg} / \mathrm{kg}$ ). Decreased diarrhea (75.75\%) was also verified when $\mathrm{CuSO}_{4}$ compared to the TBCC source. Our findings disagree with previous studies in which the percentage of animals with loose feces or diarrhea was similar between pig that received 120 and $160 \mathrm{mg} / \mathrm{kg} \mathrm{Cu}$ from $\mathrm{CuSO}_{4} \cdot 5 \mathrm{H}_{2} \mathrm{O}$ in almost overall period. Only $40-54$ days of age, the increase of concentration from 120 to $160 \mathrm{mg} / \mathrm{kg} \mathrm{Cu}$ led to a reduction of $61.19 \%$ in diarrhea (Bikker et al., 2016). Lin et al. (2020) also reported a reduction in diarrhea frequency when pig diets were supplemented with more than $80 \mathrm{mg} / \mathrm{kg}$ of TBCC or $40 \mathrm{mg} / \mathrm{kg}$ of CuPro, but no difference was observed between 80 and $200 \mathrm{mg} / \mathrm{kg}$. A reduction of $8.37 \%$ diarrhea incidence was observed in animals that received $80 \mathrm{mg} / \mathrm{kg} \mathrm{Cu}$ as CuPro compared to 80 $\mathrm{mg} / \mathrm{kg}$ TBCC.

Recent studies have suggested that the reduction diarrhea frequency was likely due to high levels $\mathrm{Cu}(160$ - $300 \mathrm{mg} / \mathrm{kg})$ which might be mediated by an effect on gut microbiota (Hill et al., 2000; Bikker et al., 2016; Zhang et al., 2017; 2019; Lin et al., 2020). Besides, the supplementation with high concentrations $\mathrm{Cu}$ in the diet may lead to a decrease of the level of amines and consequently reduce the diarrhea incidence (Zhang et al., 2019), since Cu can act as a cofactor of enzyme diamine oxidase, which is responsible for catalyzing of the oxidation of diamines and putrescine to aldehydes (Festa and Thiele 2011; Kim et al. 2008). Biogenic amines are produced by fermentation of 
amino acids by intestine microbiota from high dietary protein levels or reduced digestion and absorption in the small intestine (Neis et al., 2015). The total crude protein level used in our study is following the recommendations of Rostagno et al. (2017) to the nursery period (18.06 to $21.42 \%$ ). Thus, we believe that the diarrhea frequency results were not affected by the protein levels in the diet, but due to level and source $\mathrm{Cu}$. These data showed different mineral sources, resulting in differences in efficacy and bioavailability (Aldridge et al., 2007), and thereby, the association among level, source, and duration of supplementation can lead to divergence in results.

The duodenum of animals supplemented with $125 \mathrm{mg} / \mathrm{kg} \mathrm{Cu}$ showed better villus height and $\mathrm{VH}: \mathrm{CD}$ ratio and marginal improve $\mathrm{VH}: \mathrm{CD}$ ratio was observed in the piglets that received $\mathrm{Cu}$ as TBCC. In the ileum, there was marginal enhance in villus height when the piglets were supplemented with $\mathrm{CuSO}_{4}$ and higher $\mathrm{CD}$ when it received $125 \mathrm{mg} / \mathrm{kg}$ $\mathrm{Cu}$. The present study provides conflicting results on whether level or source affect intestinal morphology.

There are contradictory studies regarding $\mathrm{Cu}$ in high concentrations (200 - 225 $\mathrm{mg} / \mathrm{kg}$ ) improve $\mathrm{VH}$ and $\mathrm{VH}: \mathrm{CD}$ ratio in duodenum and jejunum (Zhao et al., 2007; Fry et al., 2012). Besides, Fry et al. (2012) also showed that the TBCC source was more efficient than $\mathrm{CuSO}_{4}$ to enhance $\mathrm{VH}$ in the duodenum (25.44\%) and jejunum (16.91\%). There are limited studies regarding the association of different sources with high concentrations of Cu on intestinal morphology.

The piglet newly weaned usually shows reduced growth performance and increased diarrhea frequency, which is commonly affected by adverse changes in intestinal morphology (decrease in $\mathrm{VH}$ and enhance in $\mathrm{CD}$ ), limiting animal growth (Ma et al., 2015). The results of these sudden changes are a temporary reduction in the ability of villus to absorb and digest nutrients, and the occurrence of villus atrophy and crypt hyperplasia in the gut of piglets after weaning (Li et al., 2001).

Copper is favorable for the development of the intestinal morphology, and the increase in $\mathrm{VH}: \mathrm{CD}$ ratio generally corresponds to a greater absorptive area and fewer epithelial cells needed for cell renewal (Pluske et al., 1997; Zhao et al., 2007). However, the action of Cu may be affected by the levels of zinc provided in the diet.

Hill et al. (2000) reported low plasma Cu concentration when animals were fed high levels of $\mathrm{Cu}(250 \mathrm{mg} / \mathrm{kg})$ and $\mathrm{Zn}(3,000 \mathrm{mg} / \mathrm{kg})$. It also was observed better fecal consistency score in weaned pigs receiving a dietary Cu supplement of $250 \mathrm{mg} / \mathrm{kg}$, but this study did not have analyzed intestinal morphology. On the other hand, Fry et al. (2012) evaluate pig fed $225 \mathrm{mg} / \mathrm{kg} \mathrm{Cu}$ from TBCC or $\mathrm{CuSO}_{4}$, without supplementation of 
Low dose of copper is more effective on intestinal morphology in weaned pigs

$\mathrm{Zn}$, it verified that enhanced $\mathrm{VH}$ in the duodenum in animals that received TBCC compared to $\mathrm{CuSO}_{4}$.

In the present study, $\mathrm{Zn}$ was provided in the diet of all treatments as $\mathrm{ZnO}$ at 2,500 $\mathrm{mg} / \mathrm{kg}$ from 21 to 35 days of age (pre-starter periods I and II). Based on a previous study of Hill et al. (2000) and Fry et al. (2012) we suggested that high level of $\mathrm{Zn}$ and $\mathrm{Cu}$ provided in the diet of pig affected the absorption $\mathrm{Cu}$ and the excess this mineral in feces lead to alteration on microbial composition and reduction in diarrhea frequency. However, due to the low absorption $\mathrm{Cu}$, there was no effect in intestinal morphology.

The better intestinal morphology observed in piglets supplemented with 125 $\mathrm{mg} / \mathrm{kg} \mathrm{Cu}$ allows the possibility of $\mathrm{Cu}$ inclusion to be made at lower levels than usual (200 to $250 \mathrm{mg} / \mathrm{kg}$ ). This result is important because high levels of minerals such as Cu can lead to environmental pollution (Heo et al., 2013) due to excess of them in the feces and may promote selective pressure on antimicrobial resistant bacteria (Slifierz et al., 2014). This accumulation of metal in soils is likely to have several adverse effects on the environment, and the reduction of Cu's dietary supply is one of the possible approaches to prevent this environmental risk (Jondreville et al., 2003). Besides, fed $125 \mathrm{mg} / \mathrm{kg}$ of $\mathrm{Cu}$ had a decreased fecal $\mathrm{Cu}$ excretion compared with $250 \mathrm{mg} / \mathrm{kg}$, which demonstrate that $125 \mathrm{mg} / \mathrm{kg}$ dietary $\mathrm{Cu}$, regardless of source, may be an effective environmental alternative to $250 \mathrm{mg} / \mathrm{kg}$ of CuSO4 in the diets for nursery pigs (Armstrong et al., 2004).

\section{CONCLUSION}

From the results obtained in this work, it can be concluded that the supplementation dietary with $125 \mathrm{mg} / \mathrm{kg}$ of copper can reach better villus height and villus height to crypt depth ratio in the duodenum at 63 days, with satisfactory growth performance of piglets.

\section{Acknowledgements}

The authors would like to thank the company De Heus for the support in the execution of this research.

\section{Informative notes}

The procedures and experimental use of animals were approved by the Ethic Committee on Animal Use (CEUA) with the rules issued by the National Council for Control of Animal Experimentation (CONCEA), protocol number 6255070515. 


\section{REFERENCES}

ALDRIDGE, B.E.; SADDORIS, K.L.; RADCLIFFE, J.S. Copper can be absorbed as a Cu peptide chelate through the PepT1 transporter in the jejunum of weanling pigs. Journal of Animal Science, v.85, p.154-5, 2007.

ARMSTRONG, T.A.; COOK, D.R.; WARD, M.M. et al. Effect of dietary copper source (cupric citrate and cupric sulfate) and concentration on growth performance and fecal copper excretion in weanling pigs. Journal of Animal Science, v.82, p.1234-1240, 2004.

BIKKER, P.; JONGBLOED, A.W.; VAN BAAL, J. Dose-dependent effects of copper supplementation of nursery diets on growth performance and fecal consistency in weaned pigs. Journal of Animal Science, v.94, p.181-186, 2016.

CARPENTER, C.B.; WOODWORTH, J.C.; DEROUCHEY, J.M. et al. Effects of increasing copper from tri-basic copper chloride or a copper-methionine chelate on growth performance of nursery pigs. Translational Animal Science, v.3, p.369-376, 2019.

CEMIN, H.S.; WOODWORTH, J.C.; TOKACH, M.D. et al. Effect of Zinc Oxide, Zinc Hydroxychloride, and Tri-basic Copper Chloride on Nursery Pig Performance. Kansas Agricultural Experiment Station Research Reports, v.3, p.1-9, 2017.

COBLE, K.F.; BURNETT, D.D.; DEROUCHEY, J.M. et al. Effect of diet type and added copper on growth performance, carcass characteristics, energy digestibility, gut morphology, and mucosal mRNA expression of finishing pigs. Journal of Animal Science, v.96, p.32883301, 2018.

CROMWELL, G.L.; LINDEMANN, M.D.; MONEGUE, H.J. et al. Tribasic copper chloride and copper sulfate as copper sources for weanling pigs. Journal of Animal Science, v.76, p.118-123, 1998.

DAVIS, M.E.; MAXWELL, C. V.; BROWN, D.C. et al. Effect of dietary mannan oligosaccharides and(or) pharmacological additions of copper sulfate on growth performance and immunocompetence of weanling and growing/finishing pigs. Journal of Animal Science, v.80, p.2887-2894, 2002.

DEBSKI, B. Supplementation of pigs diet with zinc and copper as alternative to conventional antimicrobials. Polish Journal of Veterinary Sciences, v.19, p.917-924. 2016. FESTA, R.A.; THIELE, D.J. Copper: an essential metal in biology. Current Biology, v.21, p.877-883, 2011.

FRY, R.S.; ASHWELL, M.S.; LLOYD, K.E. et al. Amount and source of dietary copper affects small intestine morphology, duodenal lipid peroxidation, hepatic oxidative stress, and mRNA expression of hepatic copper regulatory proteins in weanling pigs. Journal of Animal Science, v.90, p.3112-3119, 2012. 
Low dose of copper is more effective on intestinal morphology in weaned pigs

GATTÁS, G.; BARBOSA, F.F. Cobre na nutrição de aves e suínos. Revista Eletrônica Nutritime, v.1, n.3, p.117-133, 2004.

HEO, J.M.; OPAPEJU, F.O.; PLUSKE, J.R. et al. Gastrointestinal health and function in weaned pigs: a review of feeding strategies to control post-weaning diarrhoea without using in-feed antimicrobial compounds. Journal of Animal Physiology and Animal Nutrition, v.97, p.207-237, 2013.

HILL, G.M.; CROMWELL, G.L.; CRENSHAW, T.D. et al. Growth promotion effects and plasma changes from feeding high dietary concentrations of zinc and copper to weanling pigs (regional study). Journal of Animal Science, v.78, p.1010-1016, 2000.

JONDREVILLE, C.; REVY, P.S.; DOURMAD, J.Y. Dietary means to better control the environmental impact of copper and zinc by pigs from weaning to slaughter. Livestock Production Science, v.84, p.147-156, 2003.

KIM, B.E.; NEVITT, T.; THIELE, D.J. Mechanisms for copper acquisition, distribution and regulation. Nature Chemical Biology, v.4, p.176-185, 2008.

KIM, J.W.; KIL, D.Y. Determination of relative bioavailability of copper in tribasic copper chloride to copper in copper sulfate for broiler chickens based on liver and feather copper concentrations. Animal Feed Science and Technology, v.210, p.138-143, 2015.

LI, B.T.; VAN KESSEL, A.G.; CAINE, W.R. et al. Small intestinal morphology and bacterial populations in ileal digesta and feces of newly weaned pigs receiving a high dietary level of zinc oxide. Canadian Journal of Animal Science, v.81, p.511-516, 2001.

LIN, G.; GUO, Y.; LIU, B. et al. Optimal dietary copper requirements and relative bioavailability for weanling pigs fed either copper proteinate or tribasic copper chloride. Journal of Animal Science and Biotechnology, v.11, p.1-15, 2020.

MA, Y.L.; ZANTON, G.I.; ZHAO, J. et al. Multitrial analysis of the effects of copper level and source on performance in nursery pigs. Journal of Animal Science, v.93, p.606-614, 2015. NEIS, E.P.J.G.; DEJONG, C.H.C.; RENSEN, S.S. The role of microbial amino acid metabolism in host metabolism. Nutrients, v.7, p.2930-2946, 2015.

OLUKOSI, O.A.; KUIJK, S.V.; HAN, Y. Copper and zinc sources and levels of zinc inclusion influence growth performance, tissue trace mineral content, and carcass yield of broiler chickens. Poultry Science, v.0, p.1-8, 2018.

PASCOAL, L.A.F.; THOMAZ, M.C.; WATANABE, P.H. et al. Fiber sources in diets for newly weaned piglets. Revista Brasileira de Zootecnia, v.41, p.636-642, 2012.

PEKAS, J.C. Morphometry of the intestine of the pig. I. A method for complete circumsection analysis. Digestive Diseases and Sciences, v.31, p.79-89, 1986. 
PÉREZ, V.G.; WAGUESPACK, A.M.; BIDNER, T.D. et al. Additivity of effects from dietary copper and zinc on growth performance and fecal microbiota of pigs after weaning. Journal of Animal Science, v. 89, p. 414-425, 2011.

PLUSKE, J.R.; HAMPSON, D.J.; WILLIAMS, I.H. Factors influencing the structure and function of the small intestine in the weaned pig: a review. Livestock Production Science, v.51, p.215-236, 1997.

ROSTAGNO, H.S.; ALBINO, L.F.T.; HANNAS, M.I. et al. Tabelas brasileiras para aves e suínos: composição de alimentos e exigências nutricionais. Viçosa: Universidade Federal de Viçosa, 2017, 488p.

SHELTON, N.W.; TOKACH, M.D.; NELSSEN, J.L. et al. Effects of copper sulfate, tri-basic copper chloride, and zinc oxide on weanling pig performance. Journal of Animal Science, v.89, p.2440-2451, 2011.

SLIFIERZ, M.J.; FRIENDSHIP, R.; WEESE, J.S. Zinc Oxide Therapy Increases Prevalence and Persistence of Methicillin-Resistant Staphylococcus aureus in Pigs: A Randomized Controlled Trial. Zoonoses Public Health, v.62, p.301-308, 2014.

VEUM, T.L.; CARLSON, M.S.; WU, C.W. et al. Copper proteinate in weanling pig diets for enhancing growth performance and reducing fecal copper excretion compared with copper sulfate. Journal of Animal Science, v.82, p.1062-70, 2004.

ZHANG, F.; ZHENG, W.J.; GUO, R.; YAO, W. Effect of dietary copper level on the gut microbiota and its correlation with serum inflammatory cytokines in Sprague-Dawley rats. Journal of Microbiology, v.55, p.694-702, 2017.

ZHANG, F.; ZHENG, W., XUE, Y., YAO, W. Suhuai suckling piglet hindgut microbiomemetabolome responses to different dietary copper levels. Applied Microbiology and Biotechnology, v.103, p.853-868, 2019.

ZHAO, J.; HARPER, A.F.; ESTIENNE, M.J. et al. Growth performance and intestinal morphology responses in early weaned pigs to supplementation of antibiotic-free diets with an organic copper complex and spray-dried plasma protein in sanitary and nonsanitary environments. Journal of Animal Science, v.85, p.1302-1310, 2007.

ZHAO, J.; ALLEE, G.; GERLEMANN, G.; et al. Effects of a Chelated Copper as Growth Promoter on Performance and Carcass Traits in Pigs. Asian-Australasian Journal of Animal Sciences, v.27, p.965-973, 2014. 